\title{
Extraction Optimization of Soluble Compounds of Yerba Maté
}

\author{
César Sambiassi; Andrea M. Escalada and Miguel E. Schmalko* \\ Centro de Investigación y Desarrollo Tecnológico(CIDeT); Facultad de Ciencias Exactas, Químicas y Naturales; \\ Universidad Nacional de Misiones; Felix de Azara 1552; 3300 Posadas; Misiones - Argentina
}

\begin{abstract}
The objective of this research was the extraction optimization of water soluble compounds of yerba maté. Measures variables were extract concentration and weight of leaves and twigs. Controlled variables were time and temperature of extraction and water/solid relation. A surface response method of three variables was used as experimental design, with 20 experiences in each case. The range of each variable, defined in the experimental design, was: extraction time, 13.2 to 46.8 minutes; temperature, 48.2 to $81.8^{\circ} \mathrm{C}$ and water solid relation, 4.64 to $11.36 \mathrm{~g}$ water/100 $\mathrm{g}$ of dry solid. Extract weight varied from 13.14 to $29.56 \mathrm{~g}$ in leaves and 8.98 to $16.32 \mathrm{~g}$ in twigs (each one per $100 \mathrm{~g}$ of dry solid). Extract concentration varied between 2.17 and $3.43 \mathrm{~g} / 100 \mathrm{ml}$ in leaves and between 1.32 and $2.31 \mathrm{~g} / 100 \mathrm{ml}$ in twigs. The results were fit to a linear equation in each case.
\end{abstract}

Key words: Yerba maté, soluble compounds, optimization

\section{INTRODUCTION}

Production of yerba maté (Ilex paraguariensis St. Hil.) in the region of Mercosur is about 460,000 $t$ of dry product per year (Almeida Rucker and Gortari, 1997). A large part of this production is consumed like hot or cold maté or like tea. Other possibilities of its use may be as an instantaneous drink developed some years ago, as a concentrated one for carbonated drink, ice cream, yogurt, etc.

To prepare the instantaneous product or the concentrated drink, it is necessary, in a first step, to extract the soluble compounds from the solid. Escalada et al (1998) found that leaves and twigs of yerba maté had high quantities of soluble compounds, and they differed highly one from the other. Leaves had a mean content of 42.05 of soluble compounds/100 $\mathrm{g}$ of dry solid and twigs had $21.11 \mathrm{~g}$ of soluble compounds $/ 100 \mathrm{~g}$ of dry solid. Those extracts were obtained in the lab using the AOAC method (1990), with water at $100^{\circ} \mathrm{C}$. To obtain the soluble compounds, it is necessary to work at lower temperatures in order to avoid losses of volatile compounds.

One of the methods mainly used to optimize an industrial or lab process is the response surface method. In this method, the simultaneous effect of two or three variables on the response is studied (Cadden, 1988; Mudahar et al, 1989; Vega at al, 1996). The objective of this study was to optimize the extraction of soluble compounds of yerba maté using the response surface method. The variables

*Author for correspondence 
to be optimized were extract weight and concentration and the controlled variables were time and temperature of extraction and water/solid relation.

\section{MATERIALS AND METHODS}

\section{Material}

Elaborated yerba maté from local producers was used as material. Leaves and twigs were separated and ground in a mill. Each sample was put in a sieve and particles between 10/14 mesh were used as test material.

\section{Moisture content determination}

The moisture content was determined using the method of loss in mass at $103^{\circ} \mathrm{C}$ during $6 \mathrm{~h}$ (IRAM 20503). Measures were made in triplicate.

\section{Experimental equipment}

Extraction equipment consisted of a vessel with an agitator and impeller of four vanes. The vanes were welded to the rod with a $90^{\circ}$ angle. The vessel had a height of $140 \mathrm{~mm}$ and a width of 90 $\mathrm{mm}$. It had four baffles with a relation between baffle width to vessel diameter of 0.1. Agitator velocity was $60 \mathrm{rpm}$.

\section{Extraction method}

The vessel was put in the bath at a temperature given by the experimental design. Then, the sample and water were put in it and stirred during a time given by the experimental design. Then the mixture was filtered in a buchner funnel to separate big particles and through another funnel with filter paper to separate the small particles. The filtrate was evaporated in an oven at $100^{\circ} \mathrm{C}$.

\section{Experimental design}

A response surface design for three variables was used. In this design, the response is fit to an equation of three variables, like equation 1 .

$$
\begin{aligned}
& \text { y or } w=b_{0}+b_{1} x_{1}+b_{2} x_{2}+b_{3} x_{3}+b_{11} x_{1}^{2}+b_{22} x_{2}^{2}+ \\
& b_{33} x_{3}^{2}+b_{12} x_{1} x_{2}+b_{13} x_{1} x_{3}+b_{23} x_{2} x_{3}
\end{aligned}
$$

Where:

$\mathrm{y}=$ extract concentration $(\mathrm{g} / 100 \mathrm{ml})$

$\mathrm{w}=$ extract weight $(\mathrm{g} / 100 \mathrm{~g}$ dry solid $)$

$\mathrm{x}_{1}=$ reduced water/solid relation

$=(\mathrm{r}-8) / 2$

$\mathrm{r}=$ water/solid relation $(\mathrm{g}$ water/g dry solid)

$\mathrm{x}_{2}=$ reduced temperature

$=(\mathrm{T}-65) / 10$

$\mathrm{T}=$ temperature $\left({ }^{\circ} \mathrm{C}\right)$

$\mathrm{x}_{3}=$ reduced time

$=(\mathrm{t}-20) / 10$

$\mathrm{t}=$ time (minutes).

Different levels for the reduced variables are given in Table 1. Values of central point $(\mathrm{r}=8 \mathrm{~g}$ water/g dry solid and $t=20$ minutes) were obtained in previous tests.

The results were analyzed using Statgraphics Plus (1993). Mean \% Error (MPE) was calculated using equation 2.

$$
M P E=\frac{100}{n} \sum \frac{\left|y_{\text {calculated }}-y_{\text {exp erimental }}\right|}{y_{\text {exp erimental }}}
$$

Where " $n$ " is the number of experimental data.

\section{RESULTS AND DISCUSSION}

Twenty experiences for each material (leaves and twigs) were carried out according to the experimental design. Values of extract concentration and weight for leaves and twigs are given in Table 1.

For leaves, extract weight varied between 13.14 and $29.56 \mathrm{~g} / 100 \mathrm{~g}$ dry solid. Mean value for total water extract, determined using AOAC method (1990) at $100^{\circ} \mathrm{C}$ for three samples of leaves was $37.14 \mathrm{~g} / 100 \mathrm{~g}$ dry solid. Therefore, extraction efficiency for leaves varied between 35.4 and 79.6 $\%$. Extract concentration varied between 2.17 and $3.43 \mathrm{~g} / 100 \mathrm{ml}$.

For twigs, extract weight varied between 8.98 and $15.58 \mathrm{~g} / 100 \mathrm{~g}$ dry solid. Mean value of total water extract in this case was $18.14 \mathrm{~g} / 100 \mathrm{~g}$ dry solid, 
and efficiency varied between 47.8 and $83.0 \%$. Extract concentration varied between 1.32 and 2.31/ $100 \mathrm{ml}$. Higher efficiency of extraction for twigs was probably dueto lesser concentration of the extract. Equations obtained for leaves of yerba maté, considering all terms with a significative level minor to $5 \%$ were the following:

$$
\begin{aligned}
& \mathrm{y}=3.31+0.27 \mathrm{x}_{2}-0.27 \mathrm{x}_{1}{ }^{2}-0.07 \mathrm{x}_{2}^{2} \\
& \mathrm{w}=26.08+5.52 \mathrm{x}_{1}+2.11 \mathrm{x}_{2}-1.67 \mathrm{x}_{1}{ }^{2}
\end{aligned}
$$

With an MPE $=6.62$ and $4.83 \%$ for equations 3 and 4 , respectively.

Figures 1 and 2 show these two equations. The higher the temperature and the lesser water/solid relation, higher was the value of extract concentration. The higher the temperature with a relation of $10.6 \mathrm{~g}$ water/g dry solid, higher was the values of extract weight. Influence of time was not statistically significative, probably, due to high values of levels selected in the experiment and the differences between the results were in the order of the error. However, we could say that a lapse of 10 minutes was enough to reach a good extraction.

For twigs of yerba maté, the following equations, considering all terms with a significative level minor to $5 \%$ were obtained:

$\mathrm{y}=1.84-0.25 \mathrm{x}_{1}+0.12 \mathrm{x}_{2}+0.08 \mathrm{x}_{3}$

$\mathrm{w}=14.64+1.34 \mathrm{x}_{1}+0.80 \mathrm{x}_{2}+0.83 \mathrm{x}_{3}-0.81 \mathrm{x}_{1}^{2}$
The MPE for equations 5 and 6 , were $5.14 \%$ and $5.00 \%$, respectively.

Extract concentration equation was a linear one of first order and the maximum was obtained with the minor value of water/solid relation and higher temperatures and time in the work range. Extract weight had a maximum with the maximum values of temperature and time and a relation of $9.6 \mathrm{~g}$ water/g dry solid. It was very difficult to explain this behavior. But, when one applies equation 5, only a little difference is found when " $\mathrm{r}$ " varies between 8 and $11.6 \mathrm{~g}$ water/g dry solid.

\section{CONCLUSIONS}

When a surface response method was applied to optimize soluble extraction of leaves and twigs of yerba mate, the equation obtained was a function of temperature and water/solid relation in leaves and temperature, time of extractions and water/solid relation. In leaves, higher extract concentration was found with higher temperatures and minor water/solid relation. A time of 10 minutes was enough to reach a good extraction. Maximum value of extract weight was obtained at the maximum temperature and a relation of $10.6 \mathrm{~g}$ water/g dry solid. In twigs, extract concentration increased when time and temperature increased and water/solid relation decreased; while, extract weight increased when time and temperature increased with a water/dry solid relation of $9.6 \mathrm{~g} / \mathrm{g}$, but there was only little difference when this relation varied fron 8 to $11.4 \mathrm{~g}$ water/g dry solid.

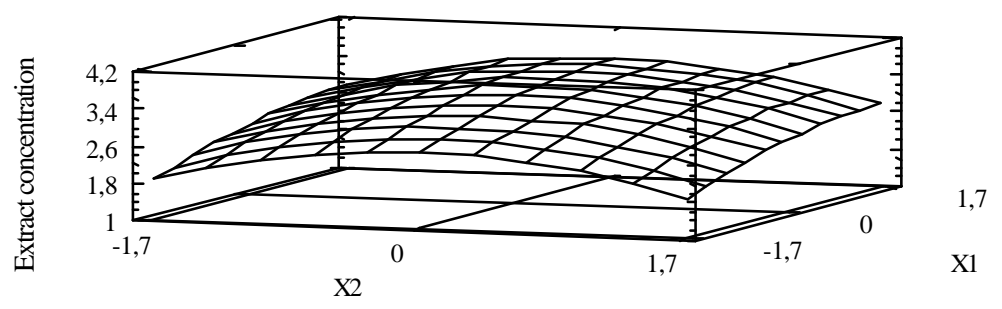

Figure 1 - Extract concentration of leaves of yerba maté, in g/100 ml 


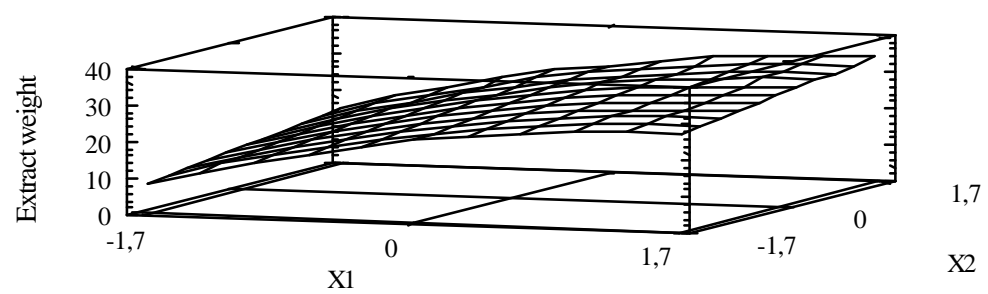

Figure 2 - Extract weight of leaves of yerba maté, in g/100 g dry solidsolid relation of $9.6 \mathrm{~g} / \mathrm{g}$, but there was only little difference when this relation varied fron 8 to $11.4 \mathrm{~g}$ water/g dry solid.

Table 1 - Values of extract concentration $(\mathrm{g} / 100 \mathrm{ml})$ and weight $(\mathrm{g} / 100 \mathrm{~g})$ for leaves and twigs of yerba maté

\begin{tabular}{|c|c|c|c|c|c|c|c|}
\hline \multirow[b]{2}{*}{ Nro } & \multicolumn{3}{|c|}{ Reduced variables } & \multicolumn{2}{|c|}{ Leaves Extract } & \multicolumn{2}{|c|}{ Twigs Extract } \\
\hline & $\mathrm{x}_{1}$ & $\mathrm{x}_{2}$ & $\mathrm{x}_{3}$ & Concentration & Weight & Concentration & Weight \\
\hline 1 & -1 & -1 & -1 & 2.34 & 14.06 & 1.89 & 11.32 \\
\hline 2 & 1 & -1 & -1 & 2.68 & 26.48 & 1.36 & 13.17 \\
\hline 3 & -1 & 1 & -1 & 2.64 & 15.84 & 1.95 & 11.84 \\
\hline 4 & 1 & 1 & -1 & 2.94 & 29.36 & 1.48 & 14.78 \\
\hline 5 & -1 & -1 & 1 & 2.38 & 14.26 & 2.10 & 15.58 \\
\hline 6 & 1 & -1 & 1 & 2.70 & 27.02 & 1.44 & 14.38 \\
\hline 7 & -1 & 1 & 1 & 3.15 & 18.92 & 2.31 & 13.84 \\
\hline 8 & 1 & 1 & 1 & 2.96 & 29.56 & 1.56 & 15.58 \\
\hline 9 & -1.68 & 0 & 0 & 2.83 & 13.14 & 1.94 & 8.98 \\
\hline 10 & 1.68 & 0 & 0 & 2.42 & 28.60 & 1.32 & 15.02 \\
\hline 11 & 0 & -1.68 & 0 & 2.17 & 17.36 & 1.34 & 10.74 \\
\hline 12 & 0 & 1.68 & 0 & 3.43 & 27.44 & 2.04 & 16.32 \\
\hline 13 & 0 & 0 & -1.68 & 3.01 & 24.04 & 1.67 & 13.38 \\
\hline 14 & 0 & 0 & 1.68 & 3.36 & 26.86 & 1.90 & 15.20 \\
\hline 15 & 0 & 0 & 0 & 3.33 & 26.62 & 1.84 & 14.72 \\
\hline 16 & 0 & 0 & 0 & 3.29 & 26.34 & 1.89 & 14.64 \\
\hline 17 & 0 & 0 & 0 & 3.30 & 26.40 & 1.82 & 14.58 \\
\hline 18 & 0 & 0 & 0 & 3.29 & 26.30 & 1.84 & 14.72 \\
\hline 19 & 0 & 0 & 0 & 3.33 & 26.60 & 1.83 & 14.60 \\
\hline 20 & 0 & 0 & 0 & 3.30 & 26,62 & 1.84 & 14.68 \\
\hline
\end{tabular}

\section{RESUMO}

O objetivo desta pesquisa foi a otimização da extração aquosa da erva mate. As variáveis medidas foram a concentração do extrato e a massa das folhas e ramos. As variáveis controladas foram: o tempo e a temperatura de extração e a relação água/sólido. Como desenho experimental foi utilizado o método de resposta superficial de três variáveis, com vinte experiências em cada caso. A faixa de variação definida para as variáveis no desenho experimental 
foram: tempo de extração, de 13,2 a 46,8 minutos; temperatura, de 48,2 a $81,8{ }^{\circ} \mathrm{C}$; relação água/sólido, de 4,64 a 11,36 gramas de água por gramas de sólido seco. A massa do extrato variou de 13,14 a 29,56 gramas para as folhas desramificadas e de 8,98 a 16,32 para os ramos (cada por 100 gramas de sólido seco). A concentração de extrato variou entre 2,17 a 3,43 g/ $100 \mathrm{ml}$ nas folhas e entre $1,32 \mathrm{e} 2,31 \mathrm{~g} / 100 \mathrm{ml}$ nos ramos. Os resultados foram, em ambos casos, ajustados para uma equação linear.

\section{REFERENCES}

Almeida Rucker, Neusa Gómez and Gortari, Javier (1997), Comércio Exterior do Mate. Cooperação Empresarial na Competitividade. In - I Congresso Sul-Americano da Erva Mate. Anais... pp. 1-9.

AOAC (1990), Official Methods of Analisis. $15^{\text {th }}$ ed. Association of Official Analytical Chemists.

Cadden, A. M. (1988), Application of Response Surface Methodology (R.S.M.) to in vitro measurement of bile salt binding under physiological condition. J. Food Sci., 53, 947-953.

Escalada M. A.; Schmalko, M. E. and Känzig, R. G. (1998), El extracto acuoso como una medida del contenido de palos de la Yerba Maté. Revista de Ciencia y Tecnología del Universidad Nacional de Misiones., 1 : (1), 40-44.
Instituto de Racionalización de Materiales - IRAM (1995), Norma 20503. Yerba maté: Determinación de la pérdida de masa a $103^{\circ} \mathrm{C}$.

Mudahar, G. S; Toledo, R. T. and Jen, J. J. (1989), Optimization of carrot dehydration process using Response Surface Methodology. J. Food Sci., 54, 714-769.

STATGRAPHICS Plus (versión 7.1 for Windows) (1993), User Manual Manugistics. Inc. Rockville, Maryland. U.S.A.

Vega, P. J.; Balabam, M. O.; Sima, C. A.; O'keefe, S. F. and Cornell, J. H. (1996), Supercritical carbondioxide extration efficiency for carotens form carrots by R.S.M. J. Food Sci., 61, 757-759. 


\section{PÁGINA}

EM

\section{BRANCO}

